\title{
EFFECT OF THE LAND USE CHANGE CHARACTERISTICS ON THE AIR POLLUTION PATTERNS ABOVE THE GREATER ATHENS AREA (GAA) AFTER 2004
}

\author{
FAMELI K.M. ${ }^{1,2, *}$ \\ ASSIMAKOPOULOS V.D. ${ }^{2}$ \\ KOTRONI V. ${ }^{2}$ \\ RETALIS A. ${ }^{2}$
}

\author{
${ }^{7}$ Devision of Environmental Physics and Meteorology, \\ Department of Physics, University of Athens, \\ Building Physics 5, University Campus, 15784 Athens, Greece \\ ${ }^{2}$ Institute for Environmental Research and Sustainable Development, \\ National Observatory of Athens, 15236 Athens, Greece
}

Received: 05/04/13

Accepted: $20 / 05 / 13$ *to whom all correspondence should be addressed: e-mail: kmfameli@phys.uoa.gr

\section{ABSTRACT}

The Attica Peninsula has experienced the rapid expansion of the Athens urban area, prior to the Athens 2004 Olympics. As a result, the distribution of pollutant sources and emission patterns has changed with a subsequent effect on the distribution of photochemical pollutants and aerosols. The purpose of the present work is to perform a comparative study of the land use changes in the rapidly developing Attica Peninsula including the Greater Athens Area (GAA) before and after 2004, the year that the Olympic Games took place, as well as of the effect of these changes on the respective pollutant distribution profiles. The land use data were provided by USGS Global Land Use/Land Cover version 2.0 Database and the updating process was fulfilled with the help of a satellite image. The area was divided into cells using a spatial resolution of $5 \times 5 \mathrm{~km}^{2}$.

Results showed that the urban grid has expanded considerably the past fifteen years while a great shift of population has been made to the eastern area of Attica. Also, new towns were created while others expanded and many factories moved out of the center of the city of Athens. Moreover, the forest land has decreased considerably in the Attica Peninsula either by continuous and extended fires or by the residential burst. The Comprehensive Air Quality Model with extensions (CAMx) was used in order to estimate $\mathrm{O}_{3}$ distribution during a recorded pollution episode. Results revealed that land use changes affected slightly the $\mathrm{O}_{3}$ concentrations and the development of a new emission inventory related to the new LULC field is necessary.

KEYWORDS: Land cover, air quality modeling, CAMx, Athens.

\section{INTRODUCTION}

The Greater Athens Area (GAA) being the largest conurbation of Greece suffers from poor air quality due to the combination of its complex topography and high volume of traffic, industrial units, central heating, construction works and other activities. Over the past decades a great number of researchers have studied both numerically and experimentally the air pollution characteristics of the GAA, (Kalambokas et al., 2012; Pateraki et al., 2010; Astitha and Kallos, 2008; Bossioli et al., 2007; Grivas et al., 2004; Martilli et al., 2003; Mavroidis et al., 2011; Chaloulakou et al., 2003; Moussiopoulos et al., 2000; Pilinis et al., 1993). The study of air pollution sources and characteristics is strongly dependent on the knowledge of the land use types as they influence a variety of processes that define air quality, the most important one being distribution of emissions (Cheng et al., 2008). Photochemical models require updated, high resolution Land Use Land Cover data (LULC). The main source for the development of reliable LULC data is the use of satellite imaging (Feldman et al., 2007) which can also be useful for updating existing data. The purpose of this study 
is thus to update the land use profile of the Greater Athens Area, including parts of Boeotia, northeastern (NE) Peloponnesus and Euboea island, with the help of a satellite image. The new LULC maps were introduced to the photochemical model CAMx in order to quantify the contribution of these changes on the distribution/behavior of photochemical pollution.

\section{PHOTOCHEMICAL MODEL DESCRIPTION}

The Comprehensive Air Quality Model with extensions (CAMx) is a photochemical model that simulates the emission, dispersion chemical reaction and removal of pollutants in the troposphere by solving the pollutant continuity equation for each chemical species on a system of nested three dimensional grids (CAMx v.4.40 Users Guide). The continuity equation is "solved" in time over a series of time steps. At each step, the continuity equation is replaced by a splitting method that calculates the contribution of each process (emission, dispersion, chemical reaction and removal) to the change of each cell's concentration which is then carried at the center of each cell volume. Eleven land use categories are used to describe surface characteristics, one for each cell (table 1). Default surface roughness values are assigned to each category by season.

Table 1. CAMx LULC Categories

\begin{tabular}{llll}
\hline \multicolumn{3}{l}{ CAMx Land use classes } & \\
\hline 1. Urban & 7. & Water \\
2. Agriculture & 8. & $\begin{array}{l}\text { Barren land } \\
\text { Non-forested }\end{array}$ \\
3. Rangeland & 9. & wetlands \\
4. Deciduous forest & Mixed agriculture and \\
5. Coniferous forest & 10. & range \\
6. Mixed forest & & \\
\hline
\end{tabular}

\section{METHODOLOGY}

\subsection{Model configuration}

The photochemical model CAMx v. 4.40 ran with the grid nesting method using two grids. The first one (coarse grid) covered South and Central Europe, Turkey and N. Africa (fig.1-left) having a spatial resolution of $15 \times 15 \mathrm{~km}^{2}$ (200x160 cells), while the second grid (fine grid) had finer resolution of $5 \times 5 \mathrm{~km}^{2}(29 \times 29$ cells) and covered the GAA, Boeotia, part of NE Peloponnesus and Euboea island (fig.1-right). The simulation period started at 00.00 (UTC) on June 17th, 2006 and ended at 24.00 (UTC) on June 19th, 2006 with the first 2 days used as a spin-up period. The mild synoptic conditions that occurred during the above period favored the development of a local circulation system (sea-breeze, fig.4) which resulted in high air pollution concentrations in the Attica peninsula. The meteorological fields (temperature, wind, pressure, water vapor, cloud/rain) used in CAMx were produced by the mesoscale meteorological model MM5. Their temporal resolution was 120 minutes for the coarse grid and 60 minutes for the fine grid while the spatial resolution was the same with the CAMx grids. Hourly gridded emissions from EMEP Centre were taken for the coarse grid, while for the fine grid an emission inventory dated back to 2000 was used which was provided by the Laboratory of Heat Transfer and Environmental Engineering (LHTEE), Aristotle University of Thessaloniki, Greece. It included hourly emission profiles for pollutants $\mathrm{SO}_{2}, \mathrm{NOx}, \mathrm{CO}, \mathrm{NH}_{3}$, NMVOCs, $\mathrm{PM}_{10}$ and $\mathrm{PM}_{2.5}$ for all kind of sources (point, line, area) divided in 10 different SNAPcategories (SNAP Level 1). The CB4 chemical mechanism was used which includes 96 reactions and 37 species ( 25 state gases and 12 radicals).

\subsection{Land use/ Land cover data (LULC)}

The LULC data that was used in this study was provided by the United States Geological Survey (USGS) Global LULC version 2.0 Database derived from the $1.1 \mathrm{~km}$ Advanced Very High Resolution Radiometer (AVHRR) for 1992. The USGS classification system includes 24 land cover categories only 14 of which are found in fine grid (fig.2). With the help of the meteorological model MM5 this data was adapted to the 11 LULC categories that CAMx uses. The area was divided into cells using a spatial resolution of $5 \times 5 \mathrm{~km}^{2}$ with Lambert Conic Conformal projection. Each cell was checked separately and correction of the LULC category was made when it was necessary. During the 

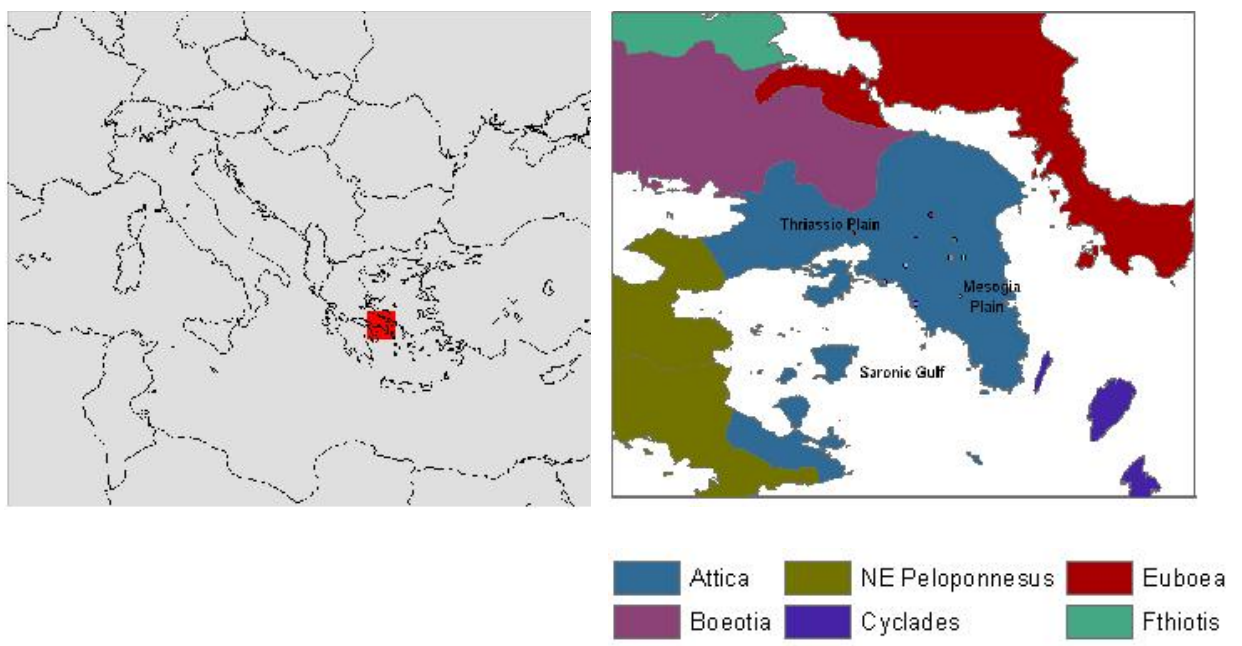

- Eleusina

- Elliniko

- Glika Nera

- Koropi

- N.Filadelfeia

- Pallini

- Penteli

- Piraeus

- Tatoi

- Thissio

Figure 1. CAMx grids - Coarse (left) and inner (right and red marked in the doarse grid), observation sites are marked with points.

Inventory process the methodology used was that of USGS Geological Survey Professional Paper 964, (www.usgs.gov). According to this paper, the LULC category that was finally adapted to a cell when multiple uses of land were recognized was the one that had the most coverage, with the exception of the built-up category which took advantage over others. The LULC field that was formed after the correction is shown in figure 2b. Afterwards, the 24 USGS land use classes were assigned to the 11 categories that CAMx uses (figure 3) and a new simulation was made. The new LULC field was then compared with land cover information derived from the Moderate Resolution Imaging Spectroradiometer (MODIS) instrument for 2006 with spatial resolution $5600 \mathrm{~m}$. The MODIS land use categories were transitioned to the CAMx ones based on their definition.

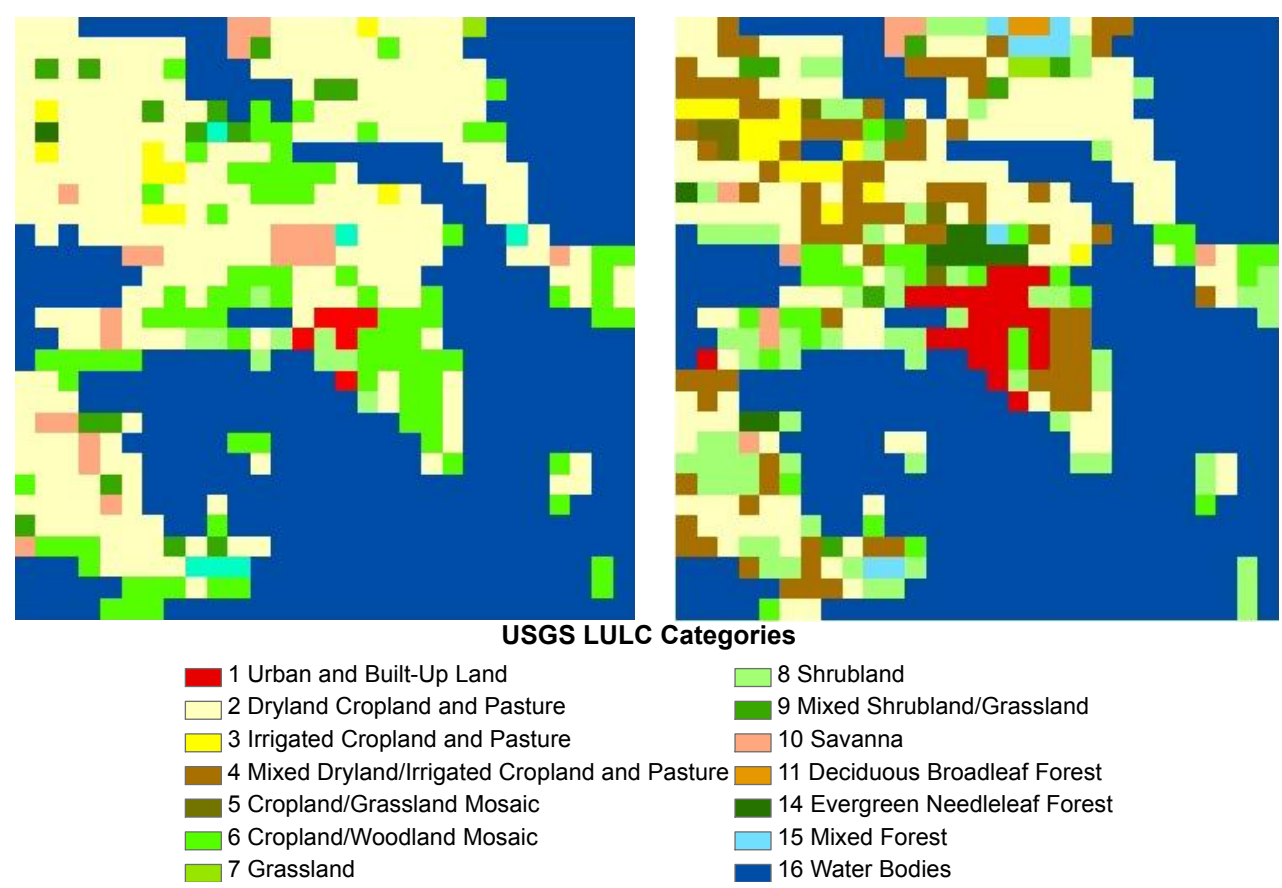

Figure 2. Initial land use field (left) updated land use field (right) using USGS LULC classification system 


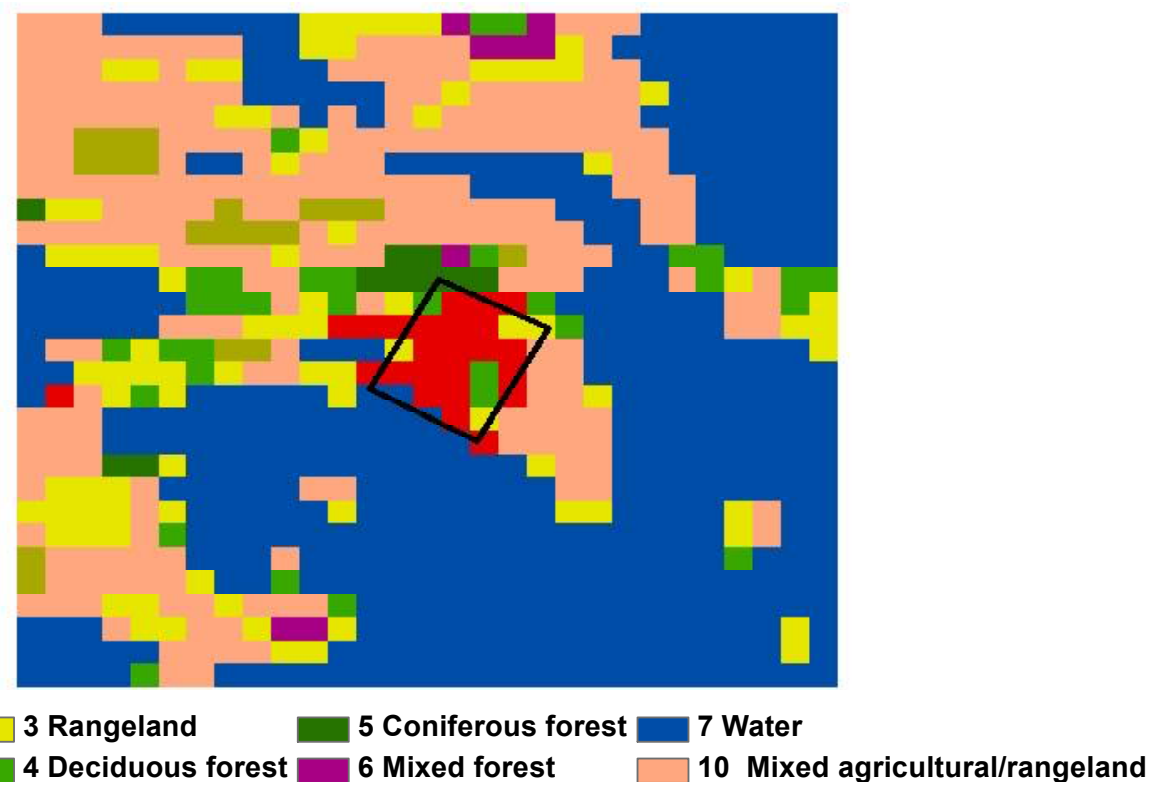

Figure 3. Updated CAMx land use field (GAA is marked with a black rectangle)

\section{RESULTS}

\subsection{Land use land cover modification}

Because of the organization of the Athens 2004 Olympic, the construction works that took place changed the landscape of the Attica peninsula. The road network was expanded, new circular roads were made (e.g., Attiki Odos) so as to serve the eastern towns of Attica and the new airport "Eleftherios Venizelos" in Spata. As a consequence, the linear residential developments along these transportation routes have extended (Mesogia Plain).

Table 2. Areal coverage over the fine grid

\begin{tabular}{|c|c|c|c|c|}
\hline $\begin{array}{l}\text { CAMx } \\
\text { class }\end{array}$ & Description & $\begin{array}{l}\text { AVHRR } \\
(1992) \\
(\%) \\
\end{array}$ & $\begin{array}{l}\text { Updated } \\
\text { LULC (2006)( } \\
\%)\end{array}$ & $\begin{array}{l}\text { MODIS } \\
(2006)(\%)\end{array}$ \\
\hline 1 & Urban & & 2.73 & 2.78 \\
\hline 2 & Agriculture & 0.71 & 2.26 & 9.6 \\
\hline 3 & $\begin{array}{l}\text { Rangeland } \\
\text { Deciduous }\end{array}$ & 5.47 & 10.58 & 3.13 \\
\hline 4 & $\begin{array}{l}\text { forest } \\
\text { Coniferous }\end{array}$ & 10.82 & 3.92 & \\
\hline 5 & forest & 0.12 & 1.2 & 0.46 \\
\hline 6 & Mixed forest & 0.71 & 0.95 & 31.72 \\
\hline 7 & Water & 50.07 & 50.17 & 52.31 \\
\hline 8 & $\begin{array}{l}\text { Barren land } \\
\text { Non-forested }\end{array}$ & & & \\
\hline 9 & $\begin{array}{l}\text { wetlands } \\
\text { Mixed } \\
\text { agriculture } \\
\text { and range }\end{array}$ & & & \\
\hline 10 & land & 32.10 & 28.18 & \\
\hline $\begin{array}{l}11 \\
\text { Sum }\end{array}$ & Rocky & & & \\
\hline Sum & & 100.00 & 100.00 & 100.00 \\
\hline
\end{tabular}

The LULC field that was formed after the updating process is shown in fig.2b. It is obvious that the urban area has expanded towards the southern and eastern parts of Attica. The land use class of cells covering these areas changed from 8 (shrub land) to 1 (urban built-up land). Many changes have also been made to the relatively open area of the Thriassio Plain, to the west of the peninsula. 
Except for the refineries that existed there for many years, the past 20 years many light industries moved from the center of Athens to this area. As a result, the area's landscape is now covered by structures (roads, plants, parking areas) and is characterized as "Industrial Park". As illustrated in fig. 3 the percentage of cells covered by urban and built-up land has changed from $6 \%$ to $23 \%$ in the GAA.

Another aspect that affected the landscape of the Attica Peninsula was the continuous and expanded fires that led to the deterioration of the forest land and the replacement of burned areas by shrubs, low vegetation and new residential areas. Moreover, in Boeotia and northeastern Peloponnesus irrigated and mixed irrigated/dry land croplands have expanded from $210 \mathrm{~km}^{2}$ in 1992 to $420 \mathrm{~km}^{2}$ in 2006 . The increase in need for agricultural products led to the improvement of the irrigation network in these areas so the agricultural activity is nowadays more organized.

The comparison between the updated LULC field and the MODIS Dataset indicated good agreement (table 2) for the urban class. However, the MODIS Dataset shows a larger spatial extent for the mixed forest class. This is due to the fact that the MODIS Dataset does not have a separate class for mixed agriculture/ range land so cells covering such areas are included in mixed forest class.
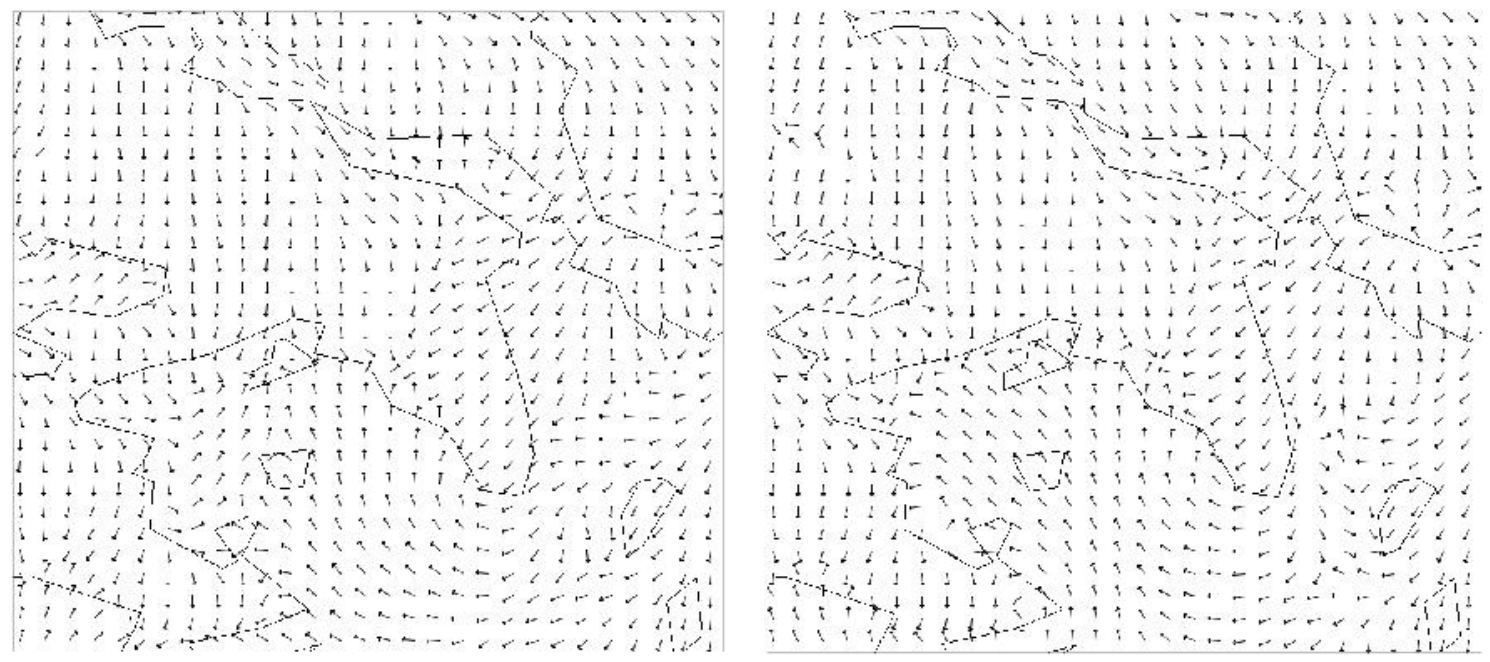

Figure 4. Wind field at $12.00 \mathrm{LT}$ (left) and $15.00 \mathrm{LST}$

\subsection{Comparison of $\mathrm{O}_{3}$ and NOx concentration profiles}

Fig. 6 presents the spatial distribution of surface ozone concentrations at $9.00 \mathrm{LT}, 12.00 \mathrm{LT}, 15.00$ LT and 18.00 LT on June 19th, 2006 with the updated LULC field as input. CAMx managed to reproduce the typical (expected) diurnal variation of $\mathrm{O}_{3}$. Early in the morning background concentrations dominated above the GAA and the surrounding areas while after sunrise the intense solar radiation drove photochemistry and led to the consequent ozone formation. Primary pollutants, emitted mainly in the center of the GAA, dispersed towards the Saronic Gulf at night due to the land breeze and then they arrived at the GAA as secondary pollutants early in the afternoon when the sea breeze was strongest (fig.4). Comparison of model results with measurements provided by the Greek Ministry of Environment revealed that CAMx didn't manage to reproduce the high values of ozone (about 110 ppb at sites Marousi and Nea Smirni and 90 ppb at site Agia Paraskevi, on June 19th) that were reported to urban stations (fig.5). However, there was less difference between observations and model results at site Pallini (located out of the urban area). Concerning NOx concentrations, the model also reproduced the diurnal variation (fig.8). Higher values were observed in the morning and in the evening at the urban area due to the road traffic emissions. The model underestimated NOx concentrations at the urban sites (Marousi, Agia Paraskevi and Nea Smirni) while NOx concentrations at site Pallini appeared to be overestimated by the model. The statistical analysis that was performed for the evaluation of the model (table 3) revealed the poor relationship between model results and observations. That was due to the fact that observations are referred to a point measurement while model concentrations are the average values of a $25 \mathrm{~km}^{2}$ area. A better grid resolution is expected to improve model's performance. Moreover, updating the input data and especially the emission inventory, would positively affect model results.

The difference in $\mathrm{O}_{3}$ concentrations $\left(\mathrm{O}_{3}\right.$ with the new LULC field $-\mathrm{O}_{3}$ with the old LULC field) for the 19th of June 2006 is illustrated in figure 7. At 9.00LT land use changes affected background ozone 
concentrations which appeared to be about $5 \mathrm{ppb}$ higher at the urban area especially for cells previously characterized as range land. The difference is greater in the early afternoon especially in the Saronic Gulf and the southern areas of Attica mainly because of expansion of the urban grid and the consequent changes in wind profile (Fameli et al. 2013). Moreover, land use changes affected wind velocities at the eastern Attica as cropland/ woodland mosaic has now been replaced by low vegetation wind velocities increased leading to higher ozone concentrations. The differences in NOx concentrations due to the land use change appear in figure 8. Land use changes did not affect considerably NOx concentrations. An increase (about 10ppb) in NOx values appeared at the southern cells (characterized as urban area at the new land use field) of the GAA in the morning.
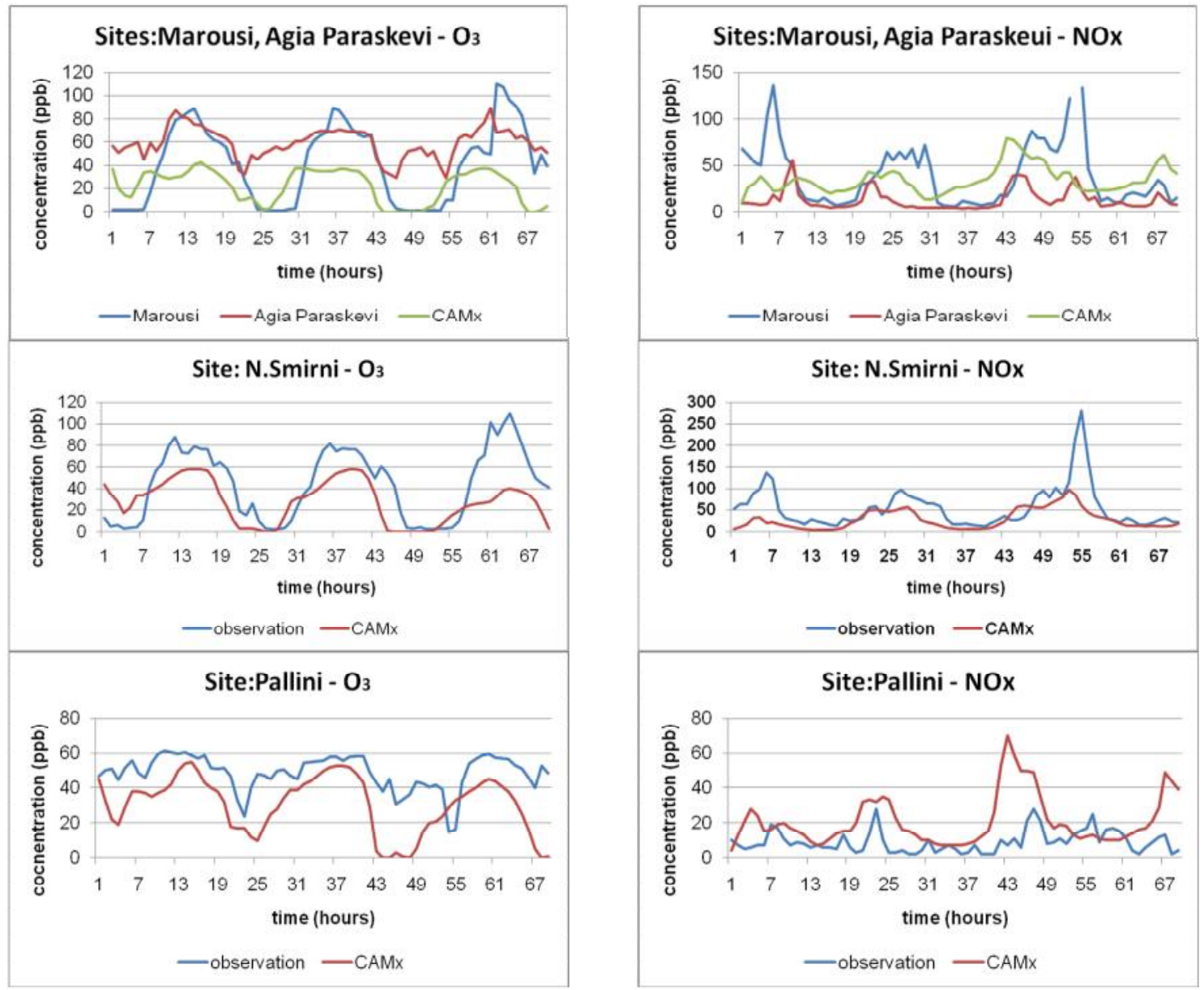

Figure 5. Temporal variation of $\mathrm{O}_{3}$ and NOx measured (Marousi, Agia Paraskevi, Nea Smirni and Pallini) and modeled (CAMx) concentrations with the updated land use from $17^{\text {th }} 0.00$ LST till $19^{\text {th }} 24.00$ LST of June 2006

Table 3. Statistical analysis between observations and model concentrations

\begin{tabular}{lllll}
\hline Site & O3 & \multicolumn{3}{l}{ NOx } \\
\hline \multirow{2}{*}{ Marousi } & $R^{2}$ & $R M S E$ & $R^{2}$ & $R M S E$ \\
\cline { 2 - 5 } Agia & 0.276 & 33 & 0.01 & 34 \\
Paraskevi & 0.442 & 38 & 0.247 & 25 \\
Nea Smirni & 0.489 & 28 & 0.385 & 45 \\
Pallini & 0.376 & 6 & 0.044 & 18 \\
\hline
\end{tabular}



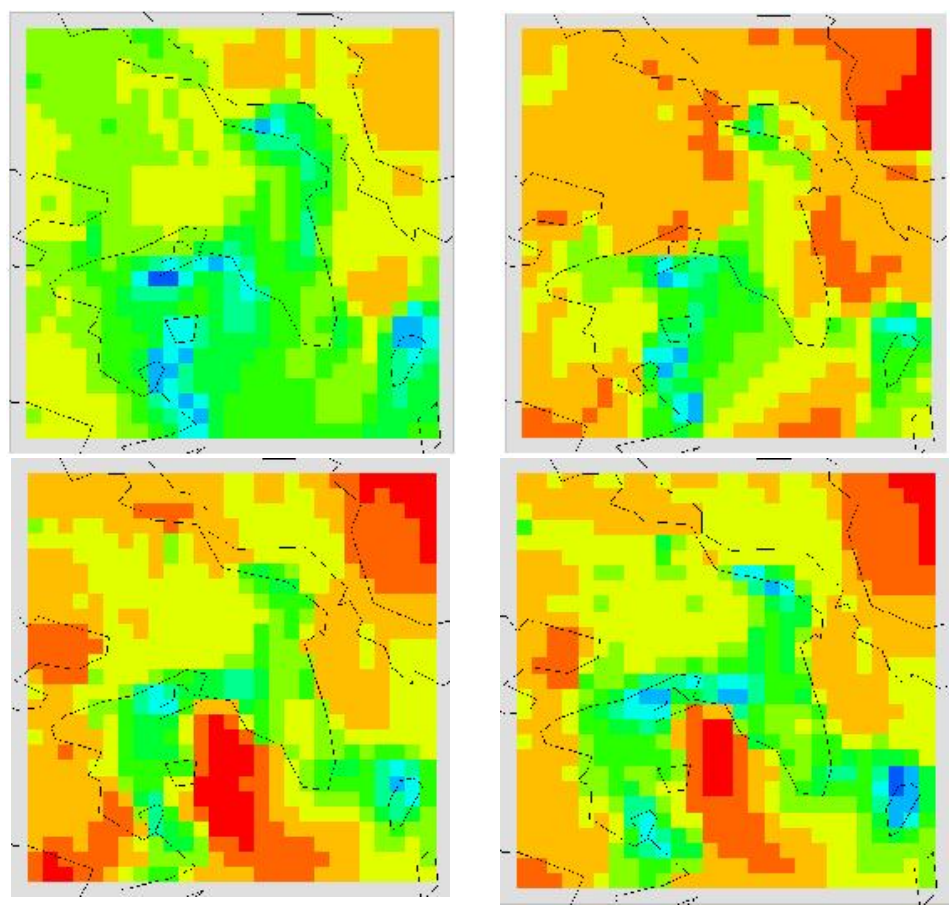

Figure 6. Surface ozone concentration on 19th June, 2006 at 9.00 LST (top left), 12.00 LST (top right), 15.00 LST (bottom left) and 18.00LST (bottom right) with the new land use field
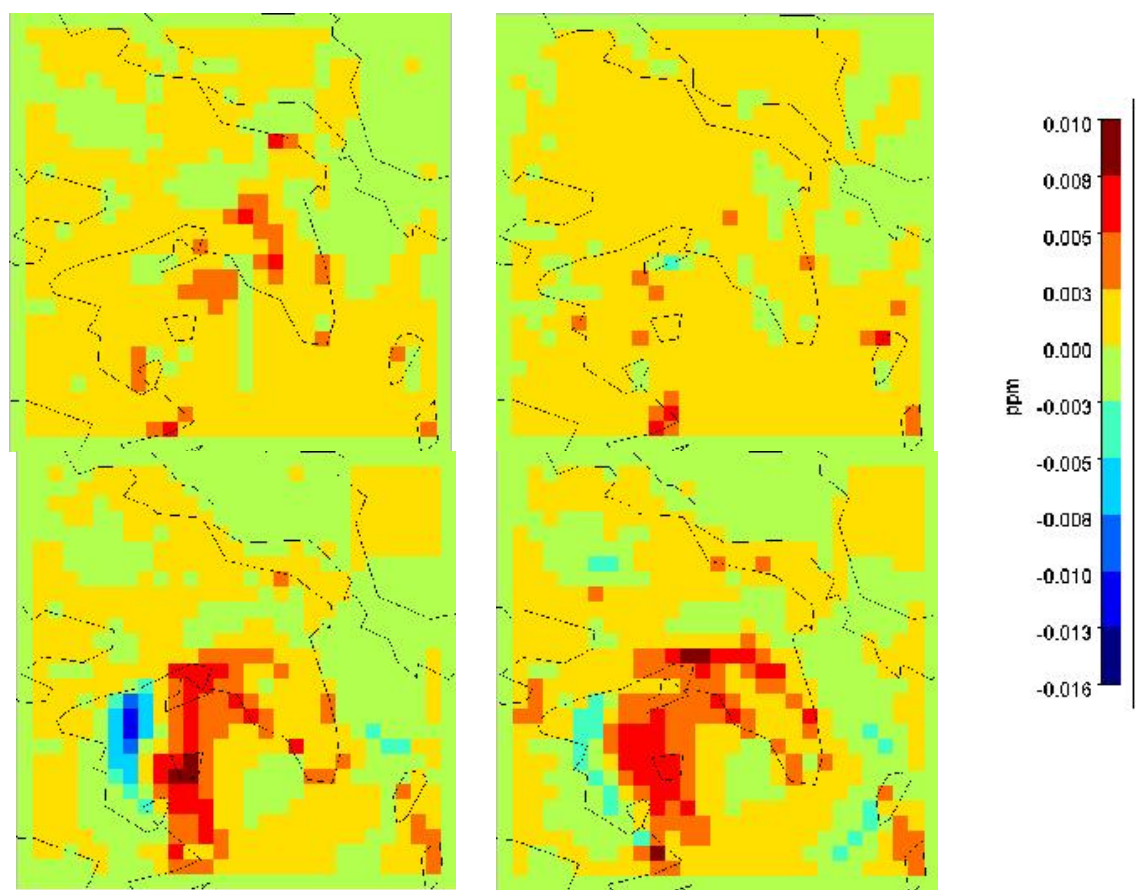

Figure 7. Difference in $\mathrm{O}_{3}$ concentrations (new LULC - old LULC) at 9.00 LST (top left) 12.00 LST (top right), 15.00 LST (bottom left) and 18.00 LST (bottom right) 

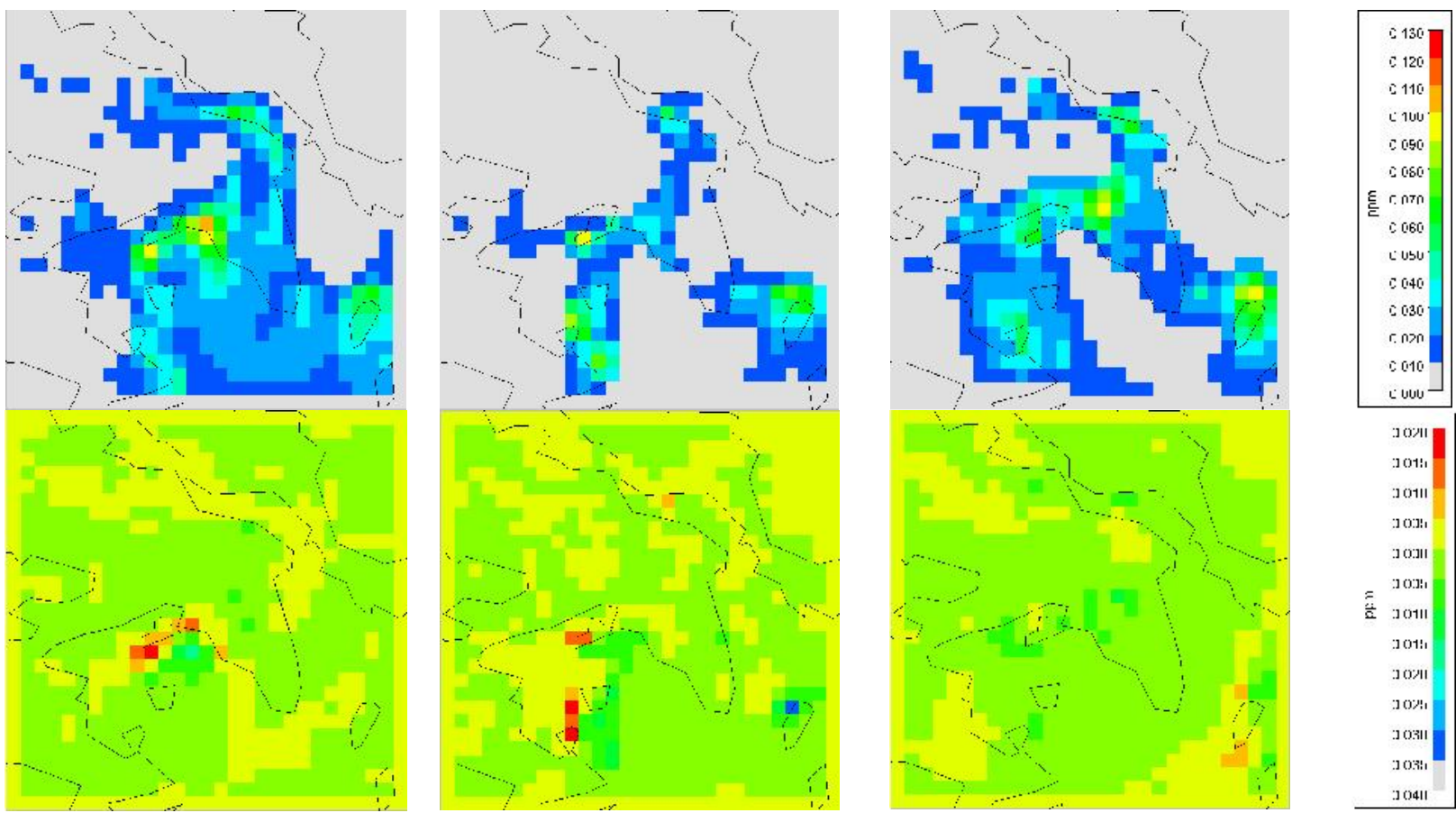

Figure 8. NOx surface concentrations at 7.00 LST (top-left), 15.00 LST (top-middle) and 21.00 LST (top-right) with the new LULC and differences in NOx concentrations (new LULC - old LULC) at 7.00 LST (bottom-left) 15.00 LST (bottom-middle) and 21.00 LST (bottom-right)

\section{CONCLUSIONS}

The organization of the Athens 2004 Olympic Games altered significantly the landscape of the GAA because of large scale construction works that took place. These changes affected the distribution of pollutant emission sources and the air quality of the area. It was thought of importance to study numerically the photochemical pollution dispersion patterns above the GAA while comparing the situation before and after 2004. In this respect, an old and an updated land use map were produced based on satellite imagery data from 2006 that was used as input to the photochemical model CAMx.

The results of this study indicate that the land use land cover profile of the GAA and its surrounding areas has changed considerably, i.e., the percentage of the urban or built-up land has increased as a consequence of the expansion of the urban grid. New towns were created while others expanded especially in the eastern area of Attica where the new Athens International Airport is located. The road network has expanded and many industries have moved to the Thriassio Plain. Moreover the irrigated croplands have increased in Boeotia. The percentage of land use categories 3 and 4 (USGS LULC classification system) in the new field is $12 \%$ while in the old field was only $1 \%$. These changes in the land use profile have affected the emission patterns as well as the photochemical pollutants concentrations $\left(\mathrm{O}_{3}, \mathrm{NOx}\right)$. The most prominent changes are seen in the areas around the southern part of Attica. Furthermore, the north and east suburbs of the GAA, where the density of the urban area has increased, have also witnessed an increase in secondary generated $\mathrm{O}_{3}$ concentrations. Therefore, it is of great importance to examine and record periodically land use changes in order to develop updated emission profiles and to produce accurate photochemical modeling studies.

\section{AKNOWLEDGEMENTS}

This research has been co-financed by the European Union (European Social Fund - ESF) and Greek national funds through the Operational Program "Education and Lifelong Learning" of the National Strategic Reference Framework (NSRF) - Research Funding Program: Heracleitus II. Investing in knowledge society through the European Social Fund. The authors would like to thank the Laboratory of Heat Transfer and Environmental Engineering (LHTEE) of the Aristotle University of Thessaloniki and Dr Astitha Marina for providing the emission inventory for the fine and coarse 
grid respectively and the Environmental Services Department of the Athens International Airport S.A for providing the observational data from site Pallini.

\section{REFERENCES}

Anderson, J.R., Hardy, E., Roach, J., Witmer, R.A (1976), Land Use and Land Cover Classification System for use with remote sensor data, Geological Survey Professional Paper 964.

Astitha, M. and Kallos, G. (2009), Gas-phase and aerosol chemistry interactions in South Europe and the Mediterranean region, Environ. Fluid Mech., 9, 3-22.

Bossioli, E., Tombrou, M., Dandou, A., Soulakelis, N. (2007), Simulation of the effects of critical factors on ozone formation and accumulation in the greater Athens area, J. . Geophys. Res., 112, D02309.

Chaloulakou, A., Kassomenos, P., Spyrellis, N., Demokritou, P., Koutrakis, P. (2003), Measurements of PM10 and PM2.5 particle concentrations in Athens, Greece, Atmos. Environ., 37, 649-660.

Cheng, Fang-Yi, Kim, Soontae, Byun, W. Daewon (2008), Application of high resolution land use and land cover data for atmospheric modeling in the Houston-Galveston Metropolitan area: Part II Air quality simulation results, Atmos. Environ., 42, 4853-4869.

Environ (2006), User's Guide to the Comprehensive Air Quality Model with Extensions (CAMx) version 4.40 (www.camx.com) .

Fameli, K.M., Assimakopoulos, V.D., Kotroni, V. (2013), On the effect of land use change on the meteorological parameters above the Greater Athens Area, Advances in Meteorology, Climatology and Atmospheric Physics. Springer Atmospheric Sciences, 73-78.

Feldman, M.S., Howard, T., McDonald-Buller, E., Mullins, G., Allen, D.T., Webb, A., Kimura, Y. (2007), Applications of satellite remote sensing data for estimating dry deposition in eastern Texas, Atmos. Environ., 41, 7562-7576.

Grivas, G., Chaloulakou, A., Samara, C., Spyrellis, N. (2004), Spatial and temporal variation of PM10 mass concentrations within the Greater Area of Athens, Greece, Water Air and Soil Poll., 158, 35771.

Kalabokas, P. D., Papayannis, A. D., Ziomas, I. (2012), A study on the atmospheric concentrations of primary and secondary air pollutants in the Athens basin performed by DOAS and DIAL measuring techniques, Sci. Total Environ., 414, 556-563.

Martilli, A., Roulet Y.-A., Junier, M., Kirchner, F., Rotach, M.W., Clappier, A. (2003), On the impact of urban surface exchange parameterisations on air quality simulations: the Athens case, Atmos. Environ., 37, 4217-4231.

Mavroidis, I. and Chaloulakou, A. (2011), Long-term trends of primary and secondary NO2 production in the Athens area - Variation of the NO2/NOx ratio, Atmos. Environ., 45; 6872-6879.

Moussiopoulos, N., Papagrigoriou, S., Bartzis, J.G., Nester, K., Van den Bergh, H., Theodoridis, G. (2000), Forecasting air quality in the Greater Athens area for the year 2004: an intercomparison of the results of four different dispersion models, Int. J. Environ. Pollut., 14, 343-353.

Pateraki, St., Asimakopoulos, D.N., Maggos, Th., Vasilakos, Ch. (2010), Particulate matter levels in a suburban Mediterranean area: Analysis of a 53-month long experimental campaign, J. Hazard Mater., 1-3, 801-811.

Pilinis, C., Kassomenos, P., Kallos, G. (1993), Modeling of the photochemical pollution in Athens, Greece. Application of the RAMS-CALGRID Modeling system, Atmos. Environ., 27B, 353-370. 